\title{
INTRODUCTION
}

\section{A Mirage on the Mekong}

It was several seconds before Bun Chenda knew what had happened. There was a thudding impact, like the blow of a hammer, which sent her falling to the ground. Then there was pain, flowering in her chest. She tasted the metallic tang of blood. As a crowd closed in blurrily around, she later said, "I felt dead already."

It was mid-February 2012, and the situation at the Manhattan Special Economic Zone in Svay Rieng was growing tense. Workers at three garment factories had walked off the job, demanding greater pay, and the Kaoway Sportswear Factory, where 21-year-old Chenda assembled running shoes, was on the verge of its own strike. The workers' demands were modest-an extra US $\$ 10$ per month to cover transport costs and a 50-cent daily food allowance-but the Taiwanese factory managers had refused to give ground. Instead, the police were deployed. They fired tear-gas at the protesters and union leaders, who responded with rocks and projectiles of their own.

Chenda wasn't the sort to hurl rocks. She was shy, with loose strands of hair that framed dark hazel eyes and pale angular features. Each morning she commuted to work from her home in Prek Pdav, a village of square homes and verdant rice fields a few kilometers from the sprawling industrial parks of Bavet, a town on the Vietnamese border. Here her mother and father owned a shack of corrugated aluminum, two cows, and a small plot of land. Chenda was 12 years when she finished school, 15 when she started working. She had been at Kaoway for six months. The tedious work brought in a small salary-just $\$ 81$ plus overtime per month-but the extra money helped her parents hire laborers for their rice paddies and keep their rickety Daelim motorbike filled with gas. Most of the Kaoway workers had a similar story, traveling each day from villages across rural Svay Rieng, gluing soles for as long as it took to help keep their families' heads above water. As Chenda told 
me, "we're tired of working in the factory, but there's no choice. We have to do it for the money."

The morning shift usually started at 7:30 a.m., but on the morning of February 20 Chenda arrived to find the gates of the factory closed. Police posted outside told her to return home; the local authorities had ordered the closure to forestall further demonstrations. As more workers arrived they grew angry and demanded to speak with the management. A protest erupted. The crowds pushed past police into the compound and a few workers began hurling chunks of concrete through the factory windows, showering the floor with glass.

Sometime after eight, a Toyota Camry edged through the crowd of protesters and pulled up to the factory's front gate. The figure who stepped out was middle-aged, with neatly parted jet-black hair. He moved languidly, a man grown comfortable in his power. After speaking with police for a moment he walked through the factory gates. As he approached a group of demonstrators, the man exchanged a few angry words. Then something snapped: he stopped, pulled out a handgun, and fired into the crowd.

Bavet, like many Asian border towns, has a shabby, desultory air. National Road 1, which doubles as the town's main drag, is lined with beer gardens and untidy concrete buildings that give way to garish casino complexes, their palm trees and faux Vegas facades fading forlornly in the tropical heat. Bavet sits at the northern tip of the Parrot's Beak, a shard of Cambodian territory that jags into southern Vietnam, close to the great delta where the Mekong River finishes its 2,700-mile journey by spilling into the South China Sea. During the Vietnam War, the area saw fierce battles between Vietnamese communists and US soldiers defending the American-backed government in Saigon (now Ho Chi Minh City), an hour's drive away down NR1. Old ideological struggles have long since given way to trade and business. Semi-trailers and tourist buses roar through town, kicking up clouds of dust. Farther out begin the factories and industrial zones, concrete oceans announced by grandiose, gold-lettered arches on the highway.

The man who shot Bun Chenda and two other female apparel workers was well known in Bavet. His name was Chhouk Bundith. He was the district governor, the most powerful figure in town, reporting to the provincial governor in Svay Rieng, and, from there, all the way up to Prime Minister Hun Sen himself. His shots at the Kaoway factory immediately made international headlines. The German sportswear giant PUMA, whose shoes were assembled by the Kaoway workers, announced an investigation. The three young victims filed complaints from their hospital beds; opposition politicians and labor rights activists demanded the governor's immediate arrest and punishment. 
In the capital, Phnom Penh, the government came under immediate pressure to act. There was a huge amount at stake. With around 400 factories employing some 475,000 workers, the apparel sector was Cambodia's largest industry, earning $\$ 5.5$ billion annually and making up the vast majority of the country's exports. Over the past 15 years the country had established a niche as an ethical manufacturing base, enforcing higher labor standards than sweatshop centers like Vietnam or Bangladesh. If things started backsliding, however, PR-conscious brands like PUMA, Gap, and H\&M wouldn't hesitate to move their operations elsewhere. In early March, the Ministry of Interior dismissed Bundith from his post and ordered his arrest.

The case should have been clear-cut. Dozens of workers had witnessed the incident and could testify that Bundith had walked into the crowd and fired at least two shots. (The two other victims, Kao Near and Nuth Sakhorn, were injured by a single bullet.) But things in Cambodia are never so simple. While some powerful people wanted to see him punished, the governor, like many high-ranking government officials, had powerful patrons determined to shield him from punishment. One of those was Men Sam An, who represented the province of Svay Rieng in the National Assembly and was the highest ranking woman in the ruling Cambodian People's Party.

In June 2013, after an acquittal and an appeal, the ex-governor was sentenced to 18 months' jail for "causing unintentional bodily harm"-a paltry charge for the daylight shooting of three unarmed protestors. But when the verdict was handed down, Bundith was nowhere to be found. His luxurious two-story villa in Bavet lay empty. He had vanished. The police claimed to have no clue about Bundith's whereabouts, even though he had been sighted several times since his disappearance. "He's staying at Men Sam An's house in Phnom Penh," said one police officer in Bavet. "It is not difficult to find him." But the truth was that the case had reached an equilibrium that suited everybody. The Cambodian authorities could claim to have punished the Kaoway shooter. And Bundith, the nowhere man, could disappear-to a realm far beyond the reach of justice.

In the Western mind, Cambodia is nearly synonymous with the terror and mass murder that engulfed the country in the mid-1970s, when the Khmer Rouge seized power and embarked on a radical experiment in communism. Led by "Brother Number One" Pol Pot, who dreamt of recreating the glories of Angkor, Cambodia's powerful premodern empire, the Khmer Rouge set about forging an agrarian arcadia of stark and uncompromising purity. They emptied the cities, abolished money, banned religion, and put the population to work in vast labor camps. For almost four years, Cambodia retreated from the world. 
By the time "Democratic Kampuchea" collapsed in early 1979, an estimated 1.7 million Cambodians - about a quarter of the population — had perished and a green land had been sown with hundreds of mass graves.

Even now, four decades on, the name of this small country still has the power to conjure. Cambodia remains an international shorthand for suffering; a hazy land of skulls and spires; an ancient civilization slipped from glory and sunk, inexplicably, in madness. "I have a gloomy view of Cambodia," Henry Kamm once remarked, reflecting on the two decades he spent covering the country for the New York Times. "It is a nation at the end of its parabola of life." 2 But despite its dark history, the Cambodian arc persists. After many years it is finally a country at peace and open to the world. Millions of foreign tourists visit each year to marvel at the great temple-city of Angkor Wat, one of the wonders of the premodern world. Today's visitor encounters a friendly people and a small country rushing to catch up with the future, seemingly impatient to leave a horrific past behind.

Cambodia's journey to the present has been tumultuous. For two decades after their overthrow by the Vietnamese army in 1979, the Khmer Rouge lived on. Throughout the 1980s, China, the United States, and their Southeast Asian allies cynically preserved the movement as a bulwark against the new Sovietaligned regime that had replaced it in Phnom Penh. The ensuing civil war dragged on for more than a decade. Then, as the Cold War thawed and a new international order dawned, Cambodia was repackaged as a democracy. A peace plan was signed and the country became the subject of one of the most ambitious and expensive United Nations peacekeeping missions ever mounted. After years of isolation, Cambodia opened to the world. Nongovernmental organizations and charities mushroomed. Foreign aid typhooned in. A victim of Cold War power politics was offered the blessings of a global community newly confident in its ability to plan and engineer democratic government.

But the democratic renaissance, such as it was, was short-lived. The government that took office following the UN-organized 1993 election was an unsteady coalition between Hun Sen of the Cambodian People's Party (CPP), which had ruled the country since 1979, and Prince Norodom Ranariddh, the son of Norodom Sihanouk, who had led Cambodia to independence in 1953. Neither leader had much interest in democracy. Cambodians had lived under authoritarian leaders since the time of Angkor, and it wasn't long before the old patterns reasserted themselves. In 1997 Hun Sen ousted Ranariddh by force and seized power for himself, leaving the UN's democratic plans in tatters.

The CPP's stabilizing power brought decades of war to an end and opened Cambodia to economic development and investment from abroad. When the Khmer Rouge finally withered in the late 1990s, a new chapter in 
the country's history began - an era of peace and economic advancement. But beneath a surface sheen of modernity and pluralism, Hun Sen continued to rule in the old way, through guile and force, through gifts and threats, through an intricate hierarchy of status and power. He has been in power ever since.

I came to this story in early 2008, arriving in Cambodia as a reporter for the Phnom Penh Post, one of the country's two English-language newspapers. The Post had an interesting history. Its long-time editor-in-chief Michael Hayes had founded the paper with his wife in July 1992, a few months into the UN mission. For its first five years, the paper was printed in Bangkok and the new editions flown in by air every two weeks. Hayes, a laconic American who always wore a crisp short-sleeved shirt and long pants despite the steamy tropical heat, had captained the publication through 16 tumultuous years, and the paper's front pages had captured all the landmark events of Cambodia's recent past: the historic 1993 election, the 1997 coup, and the final days of Pol Pot. For Hayes and his staff, each issue was "a labor of love and, at the same time, a pain in the you-know-what." ${ }^{3}$

The newsroom of the Post, which took up the second floor of Hayes's villa in central Phnom Penh, was a trove of Cambodian marginalia. Photos of old correspondents crowded the walls. A letter to the editor from the gregarious former king, Norodom Sihanouk, was taped to the side of a bookshelf, its corners curling inwards. Old press releases and reports lay in dusty piles on the floor. The back issues of the Post, bound in great annual volumes, offered a detailed chronicle of Cambodia's recent past, charting its twists and turns, its coronations and assassinations, the initial burst of democratic optimism and then the gradual fade.

Fifteen years after the UN left Cambodia, the detritus of the democratic project could be seen everywhere. The big international NGOs were comfortably entrenched, their emblems of brotherhood emblazoned on offices, signs, calendars, and reports, the last of which washed up in great dusty piles around the fringes of the newsroom. Charities and social enterprise projects abounded. International aid and its attendant foreign presence had transformed Phnom Penh into a postmodern treaty-port city, a surreal settlement of cafés, bars, and restaurants. In the countryside, NGOs pursued "community-based development" projects and rice farmers wore cast-off NGO T-shirts proclaiming, "LET'S BUILD A BETTER SOCIETY." Some of the first ideas for this book were sketched out on a notepad from the UN Office of the High Commissioner for Human Rights, which bore its blue flame-and-laurel insignia above the slogan, "Human rights for everyone, everywhere." 
The strong international presence made Cambodia an easy place to work as a journalist. Yearly business visas were available to any foreigner with fresh passport pages and the necessary fee. Unlike most Asian countries, little was officially off-limits. Foreign reporters could wander into ministry buildings and knock on doors, or travel around the country interviewing the victims of land-grabs and other abuses. In few other countries could publications like the Phnom Penh Post or the Cambodia Daily, our rivals and comrades across town, be both foreign-owned and openly critical of government. In Singapore such outspokenness would mean a rain of lawsuits; in Vietnam, a long jail sentence.

As journalists in Cambodia, our main frame of reference was the global human rights regime, that patchwork of conventions and norms that had been reinvigorated by the fall of the Soviet Union in the early 1990s. We worked closely with the country's human rights groups and NGOs, the other beneficiaries of the UN mission. Together, we formed an informational symbiosis, generating huge quantities of data, much of it detailing Cambodia's persistent failure to live up to its international human rights "obligations."

But there was something curiously abstract about the freedoms we enjoyed. No matter what we and our Khmer colleagues wrote, little seemed to change. The rich and powerful remained a law unto themselves, as they had been for as long as Cambodians could remember. Businesspeople seized land and evicted the inhabitants. Forests and natural resources were sold to Chinese and Vietnamese firms for massive sums. A man like Chhouk Bundith could shoot three young women and then brazenly flout the authority of courts that had never been free from political control. The human rights groups had their own name for all of this. They called it "impunity." But the word was so frequently deployed, and so bleached of cultural and historical context, that it soon lost much of its force.

Most Cambodians lived in a very different world than the one we inhabited in Phnom Penh. Four-fifths of them still lived in the countryside, a sodden green land of rice paddies and sugar palms, where they fished, raised crops and animals, and got on with things as best they could. Village life was organized around the local Buddhist wats, brightly colored temples where people gathered on festival days to light incense and pray to their ancestors. Though Cambodia's official religion was Theravada Buddhism, it intermingled with a host of other ancestral deities and animist guardian spirits. In front of nearly every Cambodian house, even the poorest, there was a small spirit-house where people made regular offerings-fruit, raw meat, cans of soft drinkseeking to propitiate supernatural beings who were believed to have a strong say in worldly affairs. 
At the same time, billions of dollars in international development aid had done little to improve the lot of ordinary people. Life in rural areas remained a struggle. Only a few households had access to electricity, sanitation, and clean water. Two in five Cambodian children grew up stunted. ${ }^{4}$ The country's development indicators languished in the bottom reaches of the international rankings, inviting comparison with the states of sub-Saharan Africa and blown-out Stalinist relics like North Korea. The farther from major roads people lived, the poorer and more isolated they became. With each bumpy mile, life reverted backwards in time. In some places things seemed like they hadn't changed in centuries.

But everywhere in Cambodia, even in the remotest areas, there was one constant presence. Prime Minister Hun Sen loomed over his country's political life. His name was attached to thousands of schools, often built with the donations of friendly tycoons. He was a frequent fixture on radio and TV, giving long and sometimes outrageous speeches which would insult political opponents and recount tales from his rural upbringing. In power since 1985, Hun Sen was modern Cambodia's longest-serving leader, a rugged survivor who had passed through repeated cycles of history. In the 1970s he fought for the Khmer Rouge, rising to the rank of regimental commander before defecting and becoming a member of the Vietnamese-installed government that replaced Pol Pot in 1979. Over four decades he had played many roles: apparatchik and reformer, strongman and statesman, demagogue and freewheeling free-marketeer.

Beneath these various guises Hun Sen ruled in the traditional Cambodian way, through a system of personal patronage in which money was passed upward in exchange for protection. This he married to a fierce ambition, a serrated political instinct, and a genuine ability to channel the hopes and fears of rural Cambodians. Hun Sen could be violent and unpredictable. He had little tolerance for dissent. But he and his party could also credibly claim to have ushered Cambodia into a rare era of peace and economic growth. In mid2008, despite the abuses and corruption of its rule, the CPP won a third straight election by a landslide. Seeing the failure of democracy to take root in Cambodian soil, many foreign observers decided that Khmer culture, steeped in Buddhist fatalism, was inherently passive and deferential. "Most [people] expect nothing more than they have," the American journalist Joel Brinkley wrote in his 2011 book Cambodia's Curse. "They carry no ambitions. They hold no dreams. All they want is to be left alone."

But at the same time Cambodia clearly was changing. Hun Sen's rule had unleashed economic forces that were slowly transforming society. When young women like Bun Chenda went to work in the garment factories, they often became the first members of their families to work outside rice-farming 
villages like Prek Pdav. In Cambodia there were now more mobile phones than people. The kingdom's population of 15 million was young, and with every passing year the number who had experienced Pol Pot's horrors diminished. And as the past receded, the CPP's proven system of patronage and controls, effective for so many years, began to break down. Ordinary people began standing up to demand higher wages and social justice from their government. Something was happening in Cambodia, though we weren't yet sure quite what.

By 2008, Cambodia had faded from the international headlines. When the Khmer Rouge finally collapsed in the late 1990s, it had reverted to what it had been for centuries-a small, mostly unimportant country, wedged between two more prosperous and newsworthy neighbors: the economic dynamo of Thailand, the soaring dragon of Vietnam. Aside from the sclerotic trials of former Khmer Rouge leaders, about to get underway at a UN-backed court in Phnom Penh, Cambodia's travails attracted only glancing interest.

But the story of this beautiful country deserved to be told. It had experienced some of the greatest horrors of the twentieth century and then became the focus of one of its great saving ideas-the idea that democracy could be molded and implanted in a land ravaged by war. The country that emerged from this collision of opposites was unique. Few other governments had so fully absorbed the symbols and narratives of global humanism to so little apparent effect. To put in another way, few were so open, and yet so closed. The democratic project had produced a mirage on the Mekong, an illusion of Western democratic forms behind which the country operated much as it always had.

This mirage was everywhere. It hung over Cambodia's courts and parliament. It infused the Constitution and laws that Cambodia had enacted to placate foreign aid donors. It shimmered on the streets of Phnom Penh, with their fine restaurants and refractions of First World prosperity. It was especially blinding on that day in June 2013 when Chhouk Bundith was convicted of shooting three young women, only to disappear, like a human mirage, when it came time to enforce his sentence. In Hun Sen's Cambodia, accountability and change always lay on the horizon. But what seemed tangible from a distance, on closer inspection very often melted into thin air.

The first half of this book describes the origins and history of Hun Sen's Cambodia, arising from the ashes of the Khmer Rouge regime in 1979 and navigating through the hostile years of the Cold War. Then, in the early 1990s, Cambodia joined the wider world, and schemes of a rights-based universalism collided with the realities of a poor postconflict society, burdened with a long history of autocratic rule. An important part of the story is the rise of Hun Sen, 
the figure who has done the most to shape the country's recent destiny and push back against the norms imported during the UN years. The image that emerges is of a strong leader of a weak nation-a figure who is flexible, adaptable, highly strategic, adept at the manipulation of foreign interests. As the years went by, Hun Sen became a skilled illusionist, conjuring up mirages of democracy behind which he ruled in the traditional way, through an iron fist and a canny manipulation of his country's history and culture.

The second half of the book examines the country that has emerged under Hun Sen. While the CPP has presided over peace and stability, it has left many of the country's poorest and most vulnerable citizens behind. The gale force of Cambodian capitalism has swept thousands off their land, stripped the country of its natural resources, and left many stranded on the rim of Hun Sen's economic revolution. In this sense, Cambodia's story will always be that of the Cambodian people themselves, of people like Bun Chenda and her family, and how they have experienced and responded to their country's recent evolutions. In a rapidly changing country, they, too, find ways to persist. 